\title{
IDENTIDAD Y MITO EN LA POESÍA MODERNA: OTRA MIRADA SOBRE LO MISMO*
}

\section{Naín NómeZ**}

\section{RESUMEN}

El trabajo intenta rastrear al gunas representaciones de los mitos fundacionales y culturales de la poesía chilena moderna y contemporánea, a partir de los conceptos de nación, identidad y modernidad. Para ello, se focaliza en una revisión de textos poéticos desde los albores de la Independencia hasta la época actual, considerando tanto el mito en su versión de estereotipo cultural como en su carácter de afirmación de valores y de rearticulación social.

Palabras claves: Poesía, nación, identidad, modernidad.

\section{ABSTRACT}

This paper intends to seek out representations of some of the foundational and cultural myths of modern and contemporary Chilean poetry taking as a starting point the concepts of nation, identity and modernity. In order to do so, we will focus on a revision of poetic texts starting from the dawn of Independence up through the present time, taking into account not only the myth in its stereotypical cultural version but also in its character as a reaffirmation of values and social re articulation.

Keywords: Poetry, nation, identity, modernity.

Recibido: 23.05.2003. Aprobado: 20.06.2003.

N “LA AGRICULTURA de la zona tórrida”, deAndrés Bello, uno de los poemas fundacionales de la República, al alabar los frutos americanos y la práctica agrícola, el poeta jurisconsulto hacía un fervoroso Ilamado a cultivar la tierra y a nutrir la familia y los estados. En forma ejemplar, apostrofaba a "las jóvenes naciones" a honrar el campo y la vida simple del labrador, porque eso los llevaría a morar en la libertad, tener como templo la ley y frenar la ambición. Terminaba su exordio personificando una

*Trabajo escrito en el marco del proyecto Fondecyt 10.200.028 (2002-2003).

**Profesor de Literatura en la Universidad de Santiago de Chile. Poeta y ensayista. E-mail: nnomez@lauca.usach.cl 
posteridad que aclamaría a los patriotas criollos, vencedores del león de España en Maipo, Junín y Apurima

Como sabemos, la preocupación por la conformación de las naciones y el problema de la identidad y de la cultura americana y nacional se instala no sólo en la simbología neoclásica inaugural del continente, sino que también va a permear las contradictorias luchas de los latinoamericanos durante todo el siglo XIX y buena parte del XX atravesando las representaciones y simbologías de su literatura. Durante las fases de las producciones románticas, modernistas y naturalistas, tanto los discursos directamente ideológicos como los literarios abogan por una identidad nacional, al gunos en tono menos bucólico que Bello (no hay que olvidar sus diatribas antimapuche escritas curiosamente en El Araucano), pero igualmente concentrados en la tarea común. Especialmente en la poesía modernista-naturalista, poetas como Antonio Bórquez Solar, Diego Dublé Urrutia, Carlos Pezoa Véliz o Víctor Domingo Silva se instalan en un discurso crítico que renueva (o promueve) un pathos fundacional desde una visión que contradice a la mayoría de los pensadores de la época y sus discursos públicos plagados de conservadurismo y mitologías esencialistas, incluso en los casos más liberales. Piénsese por ejemplo en Diego Barros Arana criticando la idealización del indígena en La Araucana y agregando que son bárbaros, insensibles, ociosos, borrachos, caníbales, inmorales y sin intelecto. 0 en Nicolás Palacios que defendía a los 'araucanos' (?), pero excluía a los pehuenches, patagones y huilliches, especialmente a estos últimos, que provendrían de una casta matriarcal típica, con todos los estigmas morales correspondientes. Además, su planteamiento en contra de los negros y las razas latinas era reconocido. En una posición cercana estuvieron Tancredo Pinochet, Francisco Encina, JaimeEyzaguirre, Benjamín Subercaseaux, posiciones que, con matices más o menos, aún sostienen conspicuos historiadores como Pedro M orandé, Osvaldo Lira o Gonzalo Vial².

En un principio fue el mito. Como narración homérica, como ficción en el Platón del mito de la caverna, como explicaciones primitivas del orden natural, como mitopoiesis o creación consciente, desdedonde extraesu material la literatura para crear una especie de mitología 'privada'. El mito refuerza una tradición porquesu cristalización esencializadora tiendeacongelar la historia y de allí las definiciones que la entroncan con el control social, con el fetichismo de la ideología, con los rituales vacíos y los estereo-

${ }^{1} \mathrm{~N}$. Nómez, Antología crítica de la poesía chilena, tomo I, Santiago, Lom Ediciones, 1996, pp. 53-56.

${ }^{2}$ Ver al respecto Jorge Larraín, I dentidad chilena, Santiago, Lom Ediciones, 2001. Pero también en La fonda aristocrática de Alberto Edwards, Resumen dela historia deChiledeFrancisco Encina, Raza chilena de Nicolás Palacios, Historia de Chile de Gonzalo Vial, Historia de Chile de Sergio Villalobos e Historia contemporánea de Chile de Gabriel Salazar y Julio Pinto. 


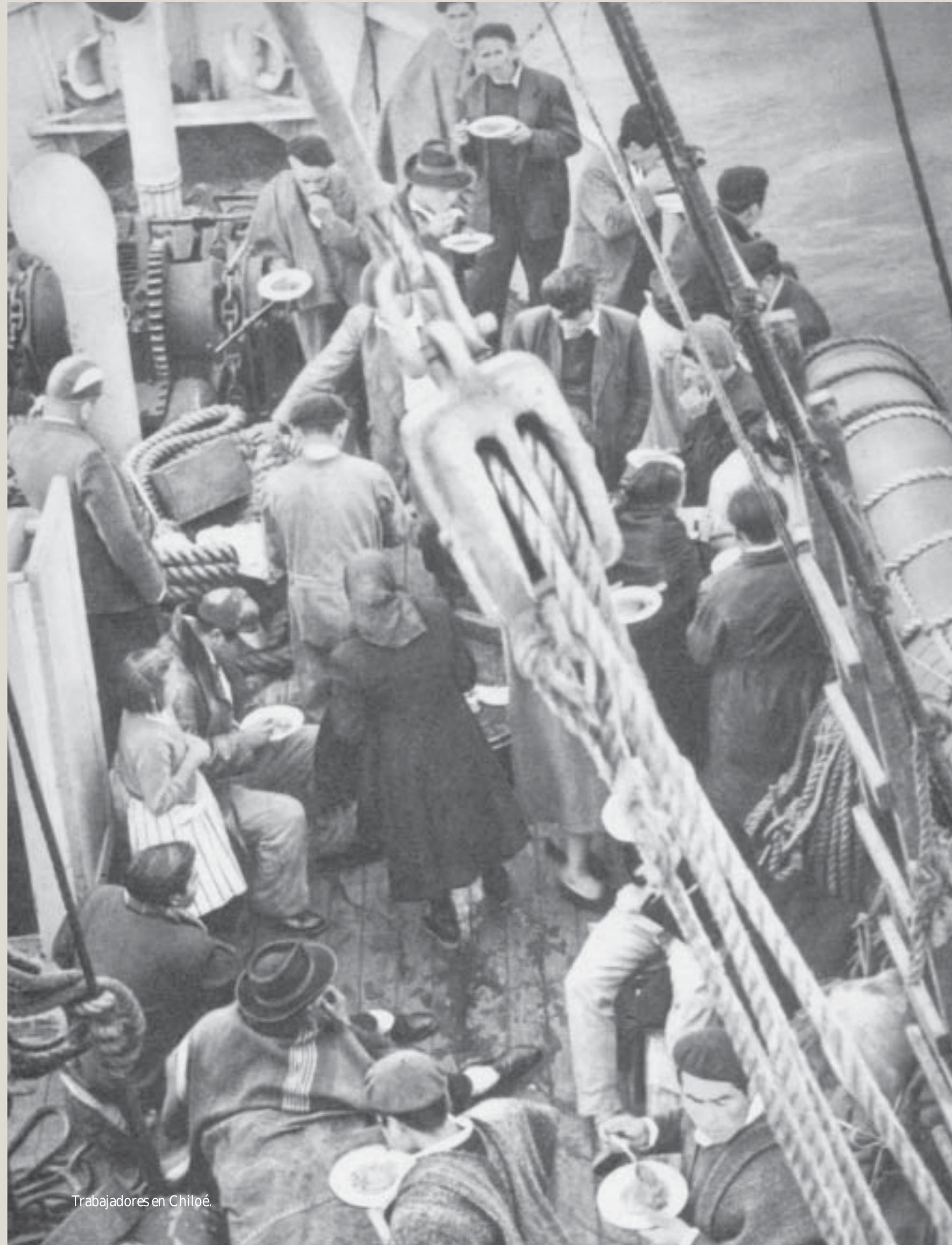


tipos. Pero también ha sido conceptualizado como una forma atenuada de intelectualidad, una forma autónoma de pensamiento y vida, un relato fabuloso o semihistórico que ratifica los orígenes y consolida la conciencia simbólica de una sociedad humana. M ircea Eliade 3 se refería a los mitos vivientes que dan significado y valor a la vida y especialmente los mitos cosmogónicos que relataban el tiempo fabuloso de los comienzos de una cultura, una sociedad o un grupo humano y también a los mitos del origen de la muerte. Son los mitos fundacionales generales que encontramos en toda cosmovisión humana, especialmente a través de la historia de las religiones. En este sentido y desde un punto de vista sociológico, el mito fundacional es también un mito cultural, ya que pertenece al conjunto de realidades simbólicas, valóricas y normativas que generan los estilos de vida y los modelos de relaciones interpersonales y sociales. Ningún mito surge fuera de la práctica social y la decantación de la tradición es un resultado de lo mismo. Levi-Strauss señalaba que el mito forma una estructura permanente que se refiere a todo el tiempo, pero que tiene infinidad de variantes ${ }^{4}$. El mito desde su punto de vista, es un instrumento lógico que formaliza un modo de pensamiento queno es distinto en lo fundamental del pensamiento racional y que se reactualiza a través de ritos, cultos, juegos y ceremonias, como ocurre en las prácticas religiosas, militares, políticas o culturales en su forma específica. Leszek Kolakowski ${ }^{5}$ critica a Carl Jung y a M ircea Eliade por pretender demostrar que mitos particulares sean concreciones espaciales y temporales del mito arquetípico común. Para él, es muy difícil poder definirlo ya que el mito sólo aparece en la práctica social y las hipótesis de Eliade ya serían parte de una conciencia mítica. A su juicio, el mito plantea el problema de la trascendencia. Frentea lo pasajero de la historia aparecela forma mítica del tiempo, que ve en el pasar de las cosas no sólo la transformación sino también la acumulación: que los hechos se hagan valores. En lo pasajero crece y permanece algo no pasajero, en la variabilidad de los sucesos se acumula al go que resiste a la ruina. La superación de la temporalidad se haría efectiva en los mitos, en donde lo pasado (aquí se entronca con la tradición) es capaz de sobrevivir en su parte no empírica y valorativa: hace frente al tiempo. La conciencia mítica es un acto de afirmar los valores. El mito no se deja convertir en estructura racionalizada. Por eso aparece en la literatura y especial mente en la poesía, donde a través de reinterpretaciones y elaboraciones se interpreta la pluralidad de su campo semántico.

Tal como veíamos en el fragmento del poema deAndrés Bello, el mito fundacional es el mito que por autonomasia fija el centro de una cultura nacional y está estrechamente ligado a las representaciones de la identidad

3M ircea Eliade, M ito y realidad, M adrid, Guadarrama, 1973.

${ }^{4}$ Claude Levy-Strauss, El pensamiento salvaje, M éxico, F.C.E, 1990.

5Leszek Kolakowsky, La presencia del mito, cap. I, M adrid, Ediciones Cátedra, 1990. 
(nacional, continental, occidental), de la nación y del Estado. Identidad y nación son casi elementos consubstanciales en el sentido que promueven la construcción e integración cultural de un grupo social. En estos conceptos semanifiesta una dimensión valórica (la del mito) que existeantes del Estado y del sistema económico que lo sustenta, conformando un espacio, un territorio, una memoria colectiva y un sentido de comunidad, que precede al establecimiento de la institucionalidad del discurso público. En Chile una vez que se ha conformado el Estado-Nación, Ios elementos del mito fundacional se desarrollan a partir de una identidad que se construye desde lo público y con los grupos sociales dominantes (económicos y políticos), por medio de una institucionalidad cultural establecida, léase educación, religión, mundo militar, estado, medios de comunicación, etc.). Esta versión pública de identidad cultural, tal como señala Jorge Larraín, es reduccionista e ideológica, porque se construye desde lo blanco, lo occidental, lo religioso, lo patriótico o lo rural, excluyendo todo lo demás: etnias, mujeres, negros, pobres, subalternos, grupos locales, etc. Si bien el desarrollo de una identidad nacional durante la creación de la república pudo constituir un paso importante como resistencia al poder extranjero, provocó al mismo tiempo una política de exclusión al interior de los grupos nacionales. De allí que la construcción identitaria sea un campo deluchas, dondeel discurso literario que se funda en la lectura de la diversidad de los modos de vida privada y social establece una reconversión de los mitos culturales públicos y juega. un papel relevante en la desmitificación de su esencialismo trascendental.

Al respecto citamos un ejemplo ampliamente conocido de este esencialismo trascendental. La narrativa de la nación se representa como un mito cultural específicamente fundacional, en cuyos orígenes se sitúa la identidad del Ejército de Chile. De acuerdo con la Historia del Ejército de Chile, publicada por el Estado Mayor en 1985, el ejército es más antiguo que la nación y provendría de los inicios de la 'raza chilena'. Allí se señala que hay un proceso de unidad racial de criollos y mestizosqueheredan "las notables virtudes militares del araucano y del soldado español". Hernán Vidal ${ }^{6}$ ha comparado el mito narrado con los procesos de la alquimia, por el uso de las palabras amalgama y crisol, que provienen de esta tradición mística y a través deun proceso parecido: al ennegrecimiento caótico, estado inicial de la materia prima, lesiguela unión mística de los opuestos femeninos y masculinos, que da como resultado el emblanquecimiento dela materia, dentro deun crisol quees un vaso hermético en forma dematriz. En la historiacitada se señala que en el proceso de mestizaje los indígenas disminuyen como producto dela guerra, el hambrey las epidemias, mientras los encomenderos mezclaron su sangre con la dejóvenes indígenas y mestizas, "Io que produjo

${ }^{6}$ Hernán Vidal, M itología militar chilena. Surrealismo desde el superego, M inneapolis, Instituto para el Estudio de Ideologías y Literatura, 1984. 
un tipo de mestizo muy blanqueado, muy cargado de sangre blanca europea... Ellos heredaron las notables virtudes militares del araucano y del soldado español"7. En este texto, los mapuches son descritos como un pueblo de atrasada civilización aunque de desarrollada inteligencia y con un perfecto dominio de los cuerpos, lo que facilita la inhibición al dolor y al cansancio. Desde el punto de vista del mito fundacional, es importante la relación que se establece entre lo militar y lo sagrado, lo que se manifiesta en el poder transformador del uniforme militar o la delimitación de los espacios propios donde tienen lugar la instrucción, los ritos, las ceremonias y las batallas y donde se instalan el orden, la verdad y la virtud. Esta relación es fundamental para la realización del ideal heroico y la renovación de la fuerza que se desprende del mito fundacional. Otro elemento que cumple con los rituales del mito fundacional es el misterio querodea el origen del héroe, en casos por ejemplo como el de Bernardo O'H iggins o de Luis Cruz M artínez por su condición de hijo natural (ligado al mito cultural del huacho y todas sus implicaciones con lo privado hecho público). En definitiva el héroe patriota forjador de la nación es un personaje ejemplar, de conducta intachabley paradigma de los valores dela raza, más ligado al mito quea la historia para la supervivencia inmutable de dichos valores.

Pero el mito dela nación se ratifica en la historia, los medios comunicacionales, la cultura popular, las comidas (los porotos, las empanadas), las imágenes (el roto), los símbolos (la bandera), los paisajes (la cordillera), los rituales (parada militar), los discursos (21 de mayo), etc. Como expresamos al comienzo, en los discursos poéticos las diversas representaciones de este mito cultural conforman un espacio mucho más conflictivo, que es planteado por posiciones diversas quese disputan el terreno para mostrar su visión de la construcción y reconstrucción de la'comunidad original' y dela'comunidad imaginada'.

En los poemas modernistas-naturalistas de fines del siglo XX y que citábamos más arriba, a diferencia de Bello, la identidad, la nación, el estado, la sociedad civil, las guerras, los ideales patrióticos seexpresan en forma híbrida y contradictoria, generalmente horadando el discurso público a partir de una simbolización de la vida cotidiana y la realidad concreta de los sujetos individuales. Deesta manera, muchas formas de la vida privada no reconocidas por lo público (y por lo tanto por las clases dominantes) aparecen en los discursos como parte de un imaginario crítico, como parte de las manifestaciones culturales populares o como rebelión frente al carácter machista, racista y legalista de la fundación de la República. Por ejemplo, un poeta ejemplar en este sentido esJuan Rafael Allende (1848-1909), poeta popular cuya vena satírica exaltó el patriotismo durante la guerra del 79, pero que

${ }^{7}$ Historia del Ejército de Chile, Santiago, Estado Mayor del Ejército de Chile, 1995, tomo 1, p. 15. 
/ de tan humildes sepelios, / que a los nuevos Evangelios / estos pobres que hoy encierra, / cuando concluya la guerra, / han de salir del osario / y juntos con otros tantos / han de ser ellos los santos / de otro nuevo calendario"11. Lo mismo hará Diego DubléU rrutia al denunciar la expulsión del campesino indígena desustierras en el poema "El lanzamiento" o Carlos PezoaVéliz en "Nada" y "El organillo" o Víctor Domingo Silva en "La nueva M arsellesa" con sus aristas anarcorrománticas. Aunque él mismo se pisará la cola con el rimbombante "Al pie de la bandera" donde la bandera como el símbolo metonímico de la patria sagrada reaparece en gloria y majestad. No es el único que lanza a la pal estra un discurso esencialista que ratifica los símbolos estereotipados de una identidad vacía de contenido y naturalizada. También lo hacen poetas de cierta prosapia como Francisco Contreras con su "Luna dela patria", M anuel M agallanes M ourea quien PezoaVéliz leenrostró su falta de sensibilidad social o Angel Cruchaga Santa M aría, quien en su "Canto a Chile", musical y rítmico, solamente ve una tradición de armonías exóticas.

Con la llegada de las vanguardias el discurso de la identidad nacional cambia y los poetas de mayor aliento iniciarán un discurso re-fundacional que moviliza los estereotipos y crea los gérmenes de nuevos mitos culturales. En este rápido escorzo habría que señalar la relevancia de la re-visión que sobre América y sus mitos fundacionales (Tala y Lagar), sobre Chile (Poema de Chile) y sobre madres y huachos (toda su obra), hace Gabriela M istral. El pasaje que su discurso poético elabora desde lo privado a lo público para poner en el tapete una cantidad de temas tapados por el discurso identitario dominante, como por ejemplo el autoritarismo, el machismo, el racismo, la exclusión de la mujer, el patriarcalismo y la racionalidad y la sanidad como atributos que dan validez al ser humano, hacen que su obra sea la de una adelantada queel tiempo lento de la crítica se ha demorado en ver. Pero no es posible aquí entrar en sus profundidades.

Me referiré brevemente a los mitos culturales en Pablo Neruda y Pablo de Rokha. En el caso de la obra de Neruda, es conocida su ligazón con los mitos originarios de fundación relacionados con el tiempo y el espacio sagrado, los mitos del origen americano y los símbolos de la génesis natural ligados al mar, el sol, la tierra, la lluvia o los ríos. Especialmente se ha estudiado extensamente la relación de la historia concreta de Chile y el continente con la re-fundación mítica, específicamente en Canto general (1950). La obra de Neruda, para bien o para mal, se declara en guerra con una parte importante de la historia oficial y construye desde el cruce del mito y la historia una re-visión posible del mundo americano, de su tradición revisitada y revisada y de su proyecto utópico basal. Apogeo de la modernidad

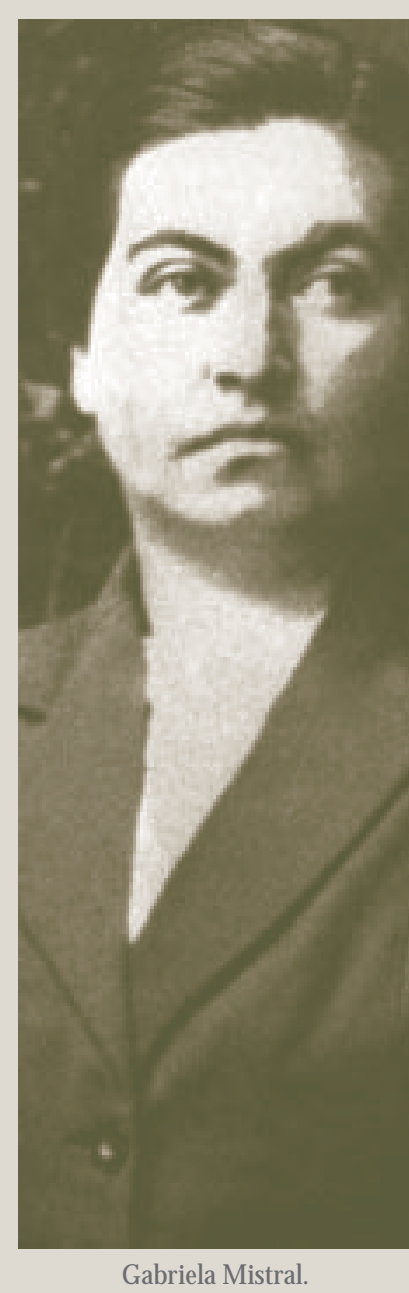

${ }^{11} \mathrm{bid}, \mathrm{pp} .158-160$. 




Pablo Neruda. frente al cuestionamiento de una identidad que se enfrenta con el espejo deforme de una tradición que la ha hecho parecer lo que no es. El poema central de la obra, "Alturas de M acchu Picchu", presenta un viajero espacial y temporal que asume la tarea prometeica de superar la conciencia de lo transitorio en una búsqueda moderna e iniciática del absoluto que se remonta a los orígenes americanos, a sus orígenes. Para subir a la montaña, primero el sujeto debe bajar a los abismos desde donde fluye la muerte colectiva, la "poderosa muerte" que no es pura negatividad, sino que trae la fecundación delo total (el arraigo terrestrey el vuelo airoso), pero en el ámbito de lo histórico y lo social. Entre otros, Cedomil Goic y Mario Rodríguez han abundado en la interpretación de este viaje iniciático como un vínculo con la comunidad y la búsqueda de un elemento esencial a la vida más allá de las formas aparienciales. En el canto VI del poema ya se establece la relación entre el dolor personal y el dolor colectivo, en donde se patentiza la aniquilación de la vida pero también la afirmación de que el reino muerto vive todavía. Hay una solidaridad que se extiende entre este reino muerto y el sujeto que lo recupera y lo catapulta al mito del proyecto común futuro. El poeta entonces exclamará: “Piedra en la piedra, el hombre dónde estuvo? / Aire en el aire, el hombre dónde estuvo? / Tiempo en el tiempo, el hombre dónde estuvo?"12. El poeta no ha podido aprehender más que un "racimo de caras o máscaras" y para encontrar esa unidad que está ausente de sus vidas, se vuelve hacia la muerte, lo que se hace a través de un viaje al centro de las cosas como un regreso a la tierra y su fugaz primavera, en una contradictoria asunción del mito del ideal heroico, ahora convertido en mito deregeneración. Así la "verdadera, abrasadora muerte", se transforma en su contrario, "una vida después detantas vidas". A hora el viajeiniciático ha terminado y en el esplendor de las ruinas (como antinomia de una modernidad que ha reprimido y simplificado la identidad del americano, del connacional), el ser humano, el poeta, el sujeto del canto se perpetúa, pero en su propia ausencia. Al responder ahora la pregunta ¿Qué era el hombre?, en el canto décimo, la noción dela muertees remplazada por la noción de la necesidad: el hambre. El ser individual sehaceplural:"Juan Cortapiedras, Juan Comefrío, Juan Piesdescalzos, etc." La crítica al otro mito fundacional es evidente.

El caso de Pablo de Rokha tiene similitudes, pero en relación a nuestro tema es diferente. Se podría señalar que su poesía responde en forma substancial a los mitos culturales elaborados por la oligarquía dominante como parte de su visión de la identidad nacional. Deestemodo, en su obra aparecen por ejemplo los paisajes, los rituales, las comidas, los elementos de la cultura popular, las imágenes rurales del huaso, el arriero, el campesino, los eventos gloriosos y la figura del roto como elemento representativo y simbólico de la chilenidad. Pero en De Rokha estos elementos adquieren un

${ }_{12}$ Pablo Neruda, O bras completas, tomo I, Buenos Aires, Editorial Losada, 1973, p. 341. 
carácter diferente, ya que refundan el estereotipo y lo convierten en una especie de palimpsesto del mito original. Un caso ejemplar de su mitología lo constituye Carta magna del continente (1948), publicada dos años antes que el Canto general. Reúne poemas escritos durante si ete años y, al igual que N eruda, intenta refundar la historia del país y del continente mezclando mito e historia. La mitificación refundadora del poeta retoma la simbólica del ideal heroico con un discurso épico que amalgama lo alto y lo bajo, la historia oficial y la reprimida, lo culto y lo popular, mostrando las contradicciones de la historia en todo su esplendor y miseria. Desfilan los personajes: Ercilla, O'H iggins, Pedro de O ña, Walter Raleigh, Pérez Rosales, Juan Godoy, los escritores, los críticos literarios, los familiares, Winétt y muchos otros de distinto calibre, en una amal gama que intenta ser la re-escritura de la historia universal, pero con más especificidad del Estado-Nación. Bardo, vate, voz de la tribu, el sujeto y el discurso marcan su propia posición revisionista, que es no sólo la de intérprete, sino también la de observador y protagonista padeciente de los sucesos que narra: "Corriendo, andando, durmiendo, cantando o llorando desde mi montaña de contradicciones e incendios, emergey avanza con las manos cortadas y un tambor negro en el pecho, estrellánd ose contra la eternidad..." ${ }^{13}$. Actitud antinómica queresalta en los títulos de los poemas donde se busca una simbiosis con la historia y la tradición, al mismo tiempo que se ejerce una rebelión refundadora, i. e. "Retrato furioso", "Lamento americano de las colonias", "Gran oda clásica a Hispanoamérica", "El Ilanto de los Ilantos", "Anecdotario completamente desaforado", “Epopeya de peripecias", "O ratoria estupenda de la República”, etc. Probablemente, el poema que concentra de mejor manera la reconversión de los estereotipos de la identidad nacional sea "Epopeya de las comidas y bebidas de Chile", en donde personajes, lugares, alimentos y acontecimientos del espacio nacional se mezclan para dar vida a una épica popular y ejemplar. Esta refundación desde abajo ruptura con los tópicos y estereotipos que en referencia al mismo campo semántico han hecho históricamente los sectores dominantes de la sociedad chilena, ya que lo que aquí se exalta es la memoria de un mundo arcaico en el cual los campesinos, los mineros, los pescadores y la vida rural vuelven a ser parte de la historia como protagonistas anónimosy reales. En cierto sentido también lo privado se convierte en gesta pública. El propio sujeto del discurso se integra a la escena como un ser anónimo más que se universaliza en su temporalidad real y simbólica: "la chichita bien madura brama en las tinajas... y nosotros nos acordaremos de todo lo que no hicimos y pudimos y debimos y quisimos hacer / como un loco asomado a la noria vacía dela al dea"14. El poema circula, va de

\footnotetext{
13Pablo deRokha, "Q uinquenio deinvierno", Carta magna deAmérica en Antología 1916-1953, Santiago, Multitud, 1954, p. 367.

${ }^{14} \mathrm{~b}$ bid, p. 397.
}

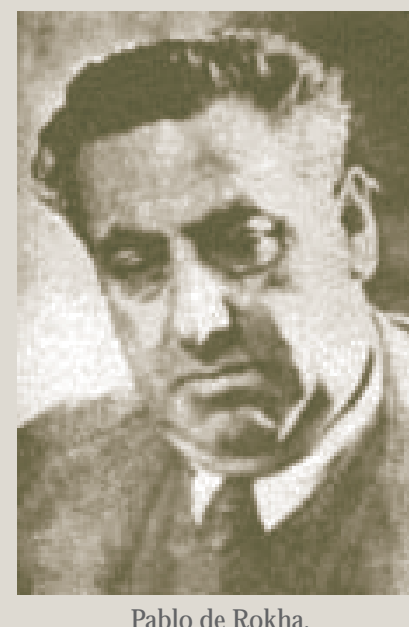

Pablo de Rokha. 


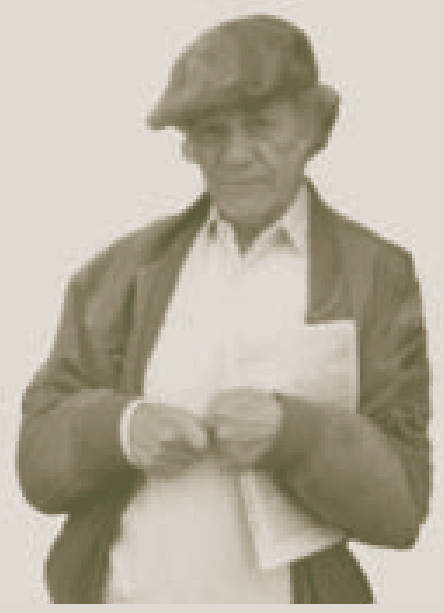

Nicanor Parra. un elemento a otro, haciendo de este continuo vaivén su propia estructura. Por eso es que el acto de comer el piure o el acontecimiento de la vendimia asumen su tradición mítica y devienen en liturgia sagrada y original. Al sacar del ámbito del puro consumismo a las comidas y bebidas y de su estereotipo al huaso y al campesino, éstos se elevan al paradigma epopéyico, cambiando signos y sentidos. Como en otros poemas, "Rotología del poroto", "Los borrachos dionisíacos" o "Campeonato de rayuela", aquí Pablo de Rokha se reapropia de una mitología vaciada de sentido y realiza una exaltación de los valores de las clases populares a partir de impulsos originarios y esenciales: el comer, el beber, la relación erótica, la capacidad de reír y llorar, la diversión y la angustia frente a la muerte.

Un breve escorzo sobre las obras de Nicanor Parra y Enrique Linn. La reescritura que la obra de Parra hace de la tradición literaria anterior, desde el romanticismo hasta las vanguardias, inaugura una resemantización del mito nacional a partir de su elaboración cotidiana y popular. Su ruptura tiene que ver en este terreno con el lugar donde se sitúa el poeta y el distanciamiento explosivo frente a cualquier intento sacralizador tradicional. Para ello le sirven la parodia, la ironía, la sátira, la paráfrasis, Ia contradicción, la polémica, el palimpsesto, la intertextualidad, la autorreflexividad, la caricatura, todos elementos que enmascaran una identidad tránsfuga, degradada y cuestionada, en fuga permanente hacia un espejo que degrada e invisiviliza. En Parra, el sujeto autorreflexivo lleva su crítica a las últimas consecuencias, para renegar de toda fundación queno sea la del propio discurso aprisionado en su espejo o su máscara, estableciendo sus límites con el mundo y disolviendo cualquier identidad salvadora (con la libertad, con el otro, con la sociedad), como la que querían los vanguardistas. Los discursos (de sobremesa) culminan en la desesperanza, el fracaso, la angustia, el absurdo, la desesperación, la incognita, la degradación, la corrosión paródica eirónica, porque somos"un embutido de ángel y bestia" y "un yogourt es lo más que podría ofrecerte".

Sin la trascendencia que la modernidad iluminista le había dado a los valores dela libertad individual, del progreso permanente dela historia y de la mitificación del futuro, el sujeto parriano fuera de cualquier metadiscurso salvador es un pobre diablo parafraseador y enmascarado, que lo único que tiene es "la muerte por delante" (El anti Lázaro). El sujeto de Parra, sujeto moderno en disolución, desprecia los metarrelatos de los proyectos fundacionales de la modernidad y se instala en los márgenes y los residuos que dejan el anonimato, la soledad, la marginalidad y la pérdida de la identidad ("Autorretrato", "Epitafio", "Soliloquio del individuo", "El pequeño burgués", "Me retracto de todo lo dicho", "Los profesores", "El anti Lázaro", etc.). Su obra se enmascara para desenmascarar toda una historia cultural del falsas mitologías y fundaciones, pero desde allí también recupera la tradición, reescribiéndola y refundándola a través de un discurso que retoma la realidad detrás del símbolo y la vuelve a llenar de sentido. 
En Parra toda fundación se asienta en un lenguaje que lo único que intenta es desmitologizarse permanentemente, ser un forado por donde el pasado y el presente se desbarrancan hacia un futuro opaco e inasible, absurdo y limitado, porque toda trascendencia desaparece en la nada. "Los vicios del mundo moderno" no permiten ninguna fundación trascendental, ni con los otros, ni con la sociedad en su conjunto, ni menos con la humanidad, a pesar de los auspiciosos augurios de una aldea global incipenteen los 50 s y una globalización cada vez más perversa en el siglo XXI. Lo único que cabe es aferrarse "a esta piltrafa divina", porque "no, la vida no tiene sentido".

En el caso de Enrique Lihn, este papel desmitificador del lenguaje se lleva al extremo. Toda fundación termina con la destrucción de la poesía misma, que renace una y otra vez de sus cenizas para reavivar sus destellos vitales. Desde N ada se escurre de 1949 hasta su Diario de muerte, ese texto póstumo escalofriante que verbaliza sus últimos días, la obra poética de Lihn busca autotransgredirse hasta llegar a la pura inanidad de un discurso que es un rumor de palabras que no pretende destruir nada, pero nos deja con nuestra mortalidad anudada al cuello, como señala Jorge Elliott. Los diferentes sujetos lihneanos asumen su propia desmitificación en la figura de un (no)vate marginal, degradado y excéntrico dentro de una sociedad decadente. Su canto es un anticanto y su mundo es grotesco. Multiplicado en una serie de máscaras autoparódicas, el hablante (los sujetos) escenifica su propia miseria en forma burlesca fuera de todo imaginario futuro o pasado.

En Lihn, no hay ni siquiera refugio en la subjetividad porqueésta se desfonda en un juego de espejos donde toda realidad se refracta en una multiplicidad de máscaras inasibles: "He perdido el sentido de mi rostro / o de tanto contarlo, se me ha vuelto infinito" (La vejez de Narciso) o donde el propio lenguaje, último refugio fundacional de la poesía, se nadifica en su entrañamiento: "Las palabras que usamos para designar las cosas están viciadas" (Nada tiene que ver el dolor...).

Todo mito fundacional parece haber caducado en la escritura de Lihn. No hay trascendencia divina, ni humana, ni siquiera discursiva. Lo quepermanece es un lenguaje espúreo y contingente que no condensa nada fuera de la fluidez de la experiencia y un camuflaje permanente de las representaciones sacralizadoras de la tradición cultural. En Lihn toda fundación y reinvención se alza sólo para ser negada a través del desgarro, el distanciamiento y el escepticismo: "Nunca salí del horroroso Chile... nunca salí de nada" (Nunca salí del horroroso Chile); "y soy mi propia ausencia frente a un espejo roto" (La vejez de Narciso); "¿A qué viene todo esto?... Basta, basta, tranquilo; aquí tiene su muerte" (M onólogo del viejo con la muerte). Tal vez en Lihn, como en Parra, sólo la escritura permite una lejana refundación de un mundo ya definitivamente perdido en medio de una modernidad que arrasa aún en su agonía: "No pude ser feliz, ello me fue negado, pero escribí".

Otras obras como las de Gonzalo Rojas, Jorge Teillier y Efraín Barquero



Enrique Lihn. 
sentidos, quecomienzan a navegar desdeel pensamiento, hacia el (con)tactoespasmo que se produce con la página en blanco" (F. M oraga). Desde allí estas poetas se enlazan al íntimo impulso de recuperar-se, desde ellas mismas como seres activos, diferentes y presentes en la sociedad y la cultura.

En este contexto se despliega la obra La bandera deChile(1991) deElvira Hernández, quien toma uno de los símbolos más ligados al mito fundacional de la patria y la nación durante un período en que tal símbolo llega casi al estereotipo, para deconstruirlo desde su propio interior con un lenguaje que se moviliza desde el emblema mujer-madre-patria hasta su construcción cultural. Como señala Fernanda M oraga, Elvira Hernández setransmuta entera en la representación femenina dela bandera, se apropia del emblema mujer-patria a través de una gradual cristalización que se origina en el hallar(se) ${ }^{16}$. Se conforma un cuerpo quecomienza a (re)escribir(se), denunciando su ausencia: "Nadie ha dicho una palabra sobre la Bandera de Chile / en el portedela tela / en todo su desierto cuadrilongo / no la han nombrado / la Bandera de Chile ausente"17. Aquí la no nombrada se nombra para decir que no la nombran. Comprende que es el cuerpo de la mujer el que está desierto, enmudecido, sin signos que la identifiquen. Símbolo de una orfandad, de una huella en sujeción de dominio, de un espacio impuesto por la marginalidad oficial, la bandera como la conciencia de la mujer se resignifica en el ejercicio deuna libertad condicionada social y culturalmente. Elvira Hernández denuncia y transgrede el mito identitario mujer-madrepatria armado desde afuera y se sumerge en el auto(re)conocimiento de su diferencia para rescatar su cuerpo y su lengua. El no decir nada, el derretirse, el descomponerse, el silenciarse de la Bandera de Chile es similar a la mutilación del cuerpo-mujer que es clausurado en su propia expresión. Agrega Fernanda M oraga que “la paralización por la represión (del lenguaje, del cuerpo, de la historia, del pensamiento) somete a la mujer a una despertenencia, por lo tanto, el deseo de escapar se construye como la percepción de un lugar de destino: un territorio interior (su cuerpo-mujer), desde donde interroga para (re)abrir su memoria al lenguaje" ${ }^{18}$. Este mismo carácter de refundación cultural adquieren los discursos de otras poetas contemporáneas chilenas, como es el caso de Marina Arrate al deconstruir los estereotipos del maquillaje femenino o al darle al tatuaje un aura simbólica de prueba iniciática, el de Soledad Fariña que desata la palabra reprimida para escarbar en los ritos de iniciación que le devuelvan la lengua o la re construcción de una ciudad ya no fundada en su habitar sino en su existencia nómade como es el caso de Carmen Berenger en Huellas de siglo, o en la

${ }^{16} \mathrm{~F}$. M oraga, "La Bandera de Chile: (Des) pliegue y (des)nudo de un cuerpo lengua(je)", Acta Literaria № 26 (Universidad de Concepción, 2001), pp. 89-98.

${ }^{17}$ Elvira Hernández, La Bandera de Chile, Santiago, Libros de Tierra Firme, 1991, p. 9.

${ }^{18}$ F. M oraga, art. cit., p. 97. 
despertenencia de una memoria siempre fragmentada y extraviada pero que se busca reconstruir en la poeta huilliche Adriana Pinda.

Es posible que el mito fundacional de la nación esté perdiendo hoy día su fuerza simbólica frente al internacionalismo del capital transnacional, la globalización política y económica y las resacas epigonales del capitalismo tardío que han culminado en el cambio del imperialismo en imperio, según Negri y $\mathrm{H}$ ardt. Sin embargo, la batalla de nuestros poetas pareciera seguir anclada en una resignificación constante de nuestros mitos culturales y fundacionales que han probado su pobreza semántica, y sin embargo a través del poder institucional y público continúan siendo parte de la hegemonía que en todos los ámbitos ejerce un grupo económico y político sobre el resto de la sociedad. La resistencia frente a la desterritorialización de los actuales signos económicos y políticos de la aldea global neoliberal (cuyos efectos últimos parecen catastróficos para la nación y para la humanidad), no implica sólo una reconversión de la tradición fundacional de la nación, sino también la necesidad de discursos que socaven las homogeneidades identitarias estereotipadas e ideologizadas. En esa tarea, la poesía sigue dibujando con fuerza la tradición soñada en cuyo movimiento se fija la tradición imaginada, la delos mitos del porvenir. Como dice Jaime Luis Huenún, poeta huilliche: "La poesía queda en el limbo de la lengua, esperando se despeje el camino hacia la memoria humana, su verdadero territorio... su destino... En medio de las alucinaciones y la fractura del tiempo real... recordar y remontar hacia el origen de la sangre y la palabra es siempre un acto subversivo" ${ }^{19}$. Sabemos que a la poesía, aunque suene un poco cursi, le corresponde revitalizar los mitos y recordarnos la nostalgia de lo que fue y de lo que pudo ser, pero además también nos escribe e inscribe la nostal gia de lo que todavía soñamos que puede ser.

\section{RefEREnCiAs}

Barquero, Efraín. 2000. Antología, Santiago, Lom Ediciones.

De Rokha, Pablo. 1954. Carta magna de América en Antología 1916-1953, "Quinquenio de invierno", Santiago, Multitud.

Edwards, Alberto. 1982. La fonda aristocrática, Santiago, Editorial Universitaria.

Eliade, M ircea. 1973. M ito y realidad, M adrid, Guadarrama.

Encina, Francisco. 1954. Resumen dela historia de Chile. Santiago, Zig Zag.

Hernández, Elvira. 1991. La Bandera de Chile, Santiago, Libros de Tierra Firme.

Historia del Ejército de Chile. 1995, tomo 1. Santiago, Estado Mayor del Ejército de Chile.

\footnotetext{
${ }^{19}$ )aime Luis Huenún, “Poeta de la tierra/ ciudadano de la página”, Pentukun 10-11 (Temuco, 2000), p. 167.
} 
Huenún, Jaime Luis. 2000. “Poeta de la tierra/ ciudadano de la página”, Pentukun 10-11 (Temuco).

Kolakowsky, Leszek. 1990. La presencia del mito, cap. I, M adrid, Ediciones Cátedra. Larraín, J orge. 2001. I dentidad chilena, Santiago, Lom Ediciones.

Levy Strauss, Claude. 1964. El pensamiento salvaje, M éxico, F.C.E.

M oraga, Fernanda. 2001. "La Bandera de Chile: (Des) pliegue y (des)nudo de un cuerpo lengua(je)", Acta Literaria № 26 (Universidad deConcepción), pp. 89-98.

Neruda, Pablo. 1973. O bras completas, tomo I, Buenos Aires, Editorial Losada.

Nicolás Palacios. 1904. Raza chilena. Santiago, Imprenta y Litografía Alemana.

Nómez, Naín. 1996. Antología crítica de la poesía chilena, tomo I, Santiago, Lom Ediciones.

Parra, Violeta. 1971. Décimas, "Me van pasando los años", La Habana, Casa de las Américas.

Sal azar, Gabriel y Julio Pinto. 2002. Historia contemporánea deChile. Santiago, Lom Ediciones.

Vidal, Hernán. 1984. Mitología militar chilena. Surrealismo desde el superego, M inneapolis, Instituto para el Estudio de Ideologías y Literatura. 
